\title{
Register of Events in Rheumatology
}

\section{January}

10th-11th ARC Medical Committee Meetings

20th-25th IV Congress of SEAPAL-AR

\section{March}

27th-28th ARC Medical Committee Meetings

\section{April}

17th-18th BARR-Annual General Meeting

25th-26th Association of Physicians of GB and IrelandAnnual Meeting

May

14th RSM (Section of Rheumatology and Rehabilitation)-AGM and Presidential Address

\section{June}

5th-6th The Heberden Round (Dr H. W. Balme)

19th-20th ARC Medical Committee Meetings

22nd-27th 1980 World Congress of Rehabilitation International-'Prevention - Integration: Priorities for the ' $80 \mathrm{~s}$ '

\section{August}

17th-22nd Royal Microscopical Society-MICRO '80

25th-29th VIII International Congress of Physical Medicine and Rehabilitation: 'Disability, Prevention and Medical Rehabilitation'

\section{October}

9th-10th ARC Medical Committee Meetings

\section{November}

20th-21st The Heberden Society Annual Meeting and Oration
Venue to be advised

Royal College of Physicians, Regent's Park, London

Manila, Philippines

Royal College of Physicians, Regent's Park, London

Charing Cross Hospital, London

London

Royal Society of Medicine, Wimpole Street, London W1

St Bartholomew's Hospital, London EC1 Royal College of Physicians, Regent's Park, London

Winnipeg Convention Centre, Winnipeg, Canada

Brighton

Stockholm, Sweden

Queen Elizabeth Hall, South Bank, London

A complete list of rheumatological meetings and courses in the UK is published in January and July of each year in the BLAR Newsletter, a copy of which is available from the Arthritis and Rheumatism Council, Faraday House, 8-10 Charing Cross Road, London WC2H 0HN. 